\title{
Standard area diagram set for olive leaf spot assessment
}

\author{
Marcos Robson Sachet ${ }^{1 *}$ Moeses Andrigo Danner ${ }^{1}$ Idemir Citadin ${ }^{1}$ \\ Rafael Henrique Pertille ${ }^{2}$ Marieli Teresinha Guerrezi ${ }^{2}$
}

\footnotetext{
${ }^{1}$ Programa de Pós-graduação em Agronomia, Departamento de Agronomia, Universidade Tecnológica Federal do Paraná (UTFPR), Via do Conhecimento, km 1, 85503-390, Pato Branco, PR, Brasil. E-mail: marcos.sachet@ufrr.br. "Corresponding author.

${ }^{2}$ Graduação em Agronomia, Departamento de Agronomia, Universidade Tecnológica Federal do Paraná (UTFPR), Pato Branco, PR, Brasil.
}

\begin{abstract}
The establishment of olive (Olea europaea) orchards in Brazil is increasing due to their economic potential and benefits to human health. However, a number of limiting factors need to be overcome, such as Olive Leaf Spot (OLS) occurrence, for olives to reach their full potential. OLS, which is caused by Fusicladium oleaginum, results in defoliation and a reduction in fruit production. This study aimed to develop a standard area diagram set (SAD) for the assessment of OLS severity under humid subtropical climate conditions. The SAD was developed with six levels of severity (1, 3, 6, 9, 12 and 15\%) and OLS severity was validated by eight inexperienced raters. Using the SAD provided an increase in accuracy, precision and concordance, while also reducing the smallest difference detectable. The proposed SAD was adequate at estimating the OLS and could be a useful tool for use in epidemiological and phytopathometry studies, evaluation of control strategies and selection of resistant genotypes. Key words: Olea europaea, olive peacock's eye, phytopatometry.
\end{abstract}

Escala diagramática para avaliação de repilo em oliveira

RESUMO: O cultivo da oliveira (Olea europaea) no Brasil é crescente devido seu potencial econômico e pelos beneficios que seus produtos oferecem à saúde humana, entretanto, alguns fatores limitantes precisam ser superados, como a ocorrência do repilo (OLS). O repilo, causado pelo fungo Fusicladium oleagineum, causa desfolha e redução da produção de azeitonas. O objetivo deste trabalho foi elaborar uma escala diagramática para auxiliar nas estimativas de severidade de repilo em oliveira em condição de clima subtropical úmido. A escala diagramática foi elaborada com 6 níveis (1, 3, 6, 9, 12 e 15\%) e validada por 8 avaliadores inexperientes. Com o uso da escala houve aumento na acurácia, precisão e concordância, também redução do menor valor de severidade detectável. A escala proposta foi adequada para estimar a severidade de repilo em oliveira, podendo ser utilizada para estudos epidemiológicos, avaliação de estratégias de controle e seleção de genótipos resistentes.

Palavras-chave: Olea europaea, olho-de-pavão, fitopatometria.

Olives (Olea europaea) are originally from the Mediterranean region of Europe and their cultivation in warm humid climates has increased the occurrence of foliar diseases (ROUBAL et al., 2013). Olive oil is famous because of its beneficial effects on human health brought about by a chemical composition, which includes fatty acids and polyphenols (MARTÍN-PELÁES et al., 2013). Leaves also have the potential for use, since they contain nutrients and polyphenols (CAVALHEIRO et al., 2014; VOGEL et al., 2015). Brazil is the second largest import market for olives and olive oil in the world (TERAMOTO et al., 2013; WREGE et al., 2015a), around US\$ 400 million per year (FAOSTAT, 2015). However, per capita olive oil consumption $(0.2 \mathrm{~L})$ is lower compared with other countries, such as Greece (20L), Spain (12L), Italy (12L) and Portugal (9L) (ALMEIDA et al., 2015).

Combining the need to increase production and consumption, while reducing imports, researchers have conducted a number of important olive studies in Brazil, on subjects such as cutting propagation (PENSO et al., 2016), indication of more favorable areas for cultivation (WREGE et al., 2015a; WREGE et al., 2015b), identification of pests (RICALDE et al., 2015) and olive and oil quality (OLIVEIRA et al., 2012). However, studies regarding 
olive plant pathology under Brazilian climate conditions have not yet received sufficient attention. This is an important study area as increased olive cultivation in Brazil could result in increased spending and reduced production due to diseases occurrence.

Olive leaf spot (OLS, also called repilo or peacock's eye) is the most important disease of olives and is due to Spilocaea oleaginea (synonym: Cycloconium oleagineum), reclassified as Fusicladium oleagineum (SCHUBERT et al., 2003). Signs of the disease include circular brown spots on leaves that can be present with or without a yellowish halo, these occur from autumn to early spring (May to September), a period of mild temperatures and high humidity in southern Brazil, the ideal conditions for OLS development. The primary inoculum is provided by latent infections on leaves, which produce and disseminate conidia via rain in autumn (OBANOR et al., 2011). Inefficient control of OLS leads to leaf fall, which can reduce fruit quality and production by over 20\% (ROUBAL et al., 2013).

The SDA Normative Instruction No. 19 (Brazilian Official Gazette, August 16, 2012) aims to prevent the introduction of new pathogen sources via imported olive plants. However, OLS is already present in the main cultivation areas of Brazil. Currently there are no licensed fungicides for olive crops in Brazil (MAPA-AGROFIT) and only sparse information about OLS resistant cultivars is available. These two problems are the principle bottlenecks for olive crop expansion in Brazil.

To advance OLS control there is a need for accurate disease assessment. The main disease assessment methodology was presented by MacDONALD et al. (2000), who demonstrated how to make the latent lesions visible using $\mathrm{NaOH}$ and estimate spot area and number. Spot area is highly correlated to spot number, which is the variable most easily measured. This methodology; however, presents some inconveniences: there is no standard area diagram set (SAD) to assist with visual estimates; it is infeasible to perform disease analysis on the same leaves over the long-term; distinct spot size and the merging of lesions hinder the estimation of spot number and indirectly OLS severity. Therefore, this study aimed to develop a SAD for the assessment of OLS severity in humid subtropical climate conditions.

Leaves from 96 olive trees of the 'Arbequina' and 'Koroneiki' cultivars were collected during the winter of 2015, from the Experimental Area of the Federal University of Technology - Paraná, Campus Pato Branco $\left(26^{\circ} 10^{\prime} \mathrm{S} ; 52^{\circ} 41^{\prime} \mathrm{W}, 764 \mathrm{~m}\right)$, the climate is $\mathrm{Cfa}$ (humid subtropical with warm summers) according to Köppen's classification (ALVARES et al., 2013). No fungicide was applied to the olive orchard during the evaluation cycle. Leaves exhibiting signs of OLS were scanned and the OLS severity estimated using the software AFSoft (EMBRAPA - Instrumentação Agropecuária).

For the validation of the SAD, eight people, without disease assessment experience, made estimates for 50 random images with and without the proposed SAD. OLS images (228 pictures), of known severity, were inserted into the Disease Plan spreadsheet, which performs the randomization of images, estimate recording and agreement statistics (SACHET et al., 2016). The precision, accuracy, deviations from the ideal projection, Lin's concordant correlation coefficient as shown by NICOLI et al. (2015) and the smallest difference detectable value based on the random effect of the one-way ANOVA corresponding to the least significant difference (DMS- $t$ com $\mathrm{P}=0.05$ ) were evaluated. The SAD was developed with six levels: 1, 3, 6, 9, 12 and 15\% (Figure 1), the last level was higher than the real maximum severity observed (13.8\%), with diagrams being generated from standard leaf (edge) and lesion shapes (circles). For diagram generation, area measurement was based on the image binarization process and counting of pixels using the software ImageJ.

The use of SAD increased significantly $(\mathrm{P} \leq 0.05)$ the precision ( 0.72 to 0.87$)$, accuracy $(0.91$ to 0.98$)$ and concordant correlation coefficient (0.66 to 0.86$)$, in relation to OLS severity assessment without SAD. The estimated $u$ values (difference between the line of regression and the concordant line) approached zero (ideal value) with the use of SAD (0.002), while for assessments without SAD it was 0.17. Raters began to demonstrate greater ability to estimate the real severity level with the aid of SAD, since the SDD was lower with SAD than without $(1.91 \%$ and $3.91 \%$ respectively), reducing the lower value from 


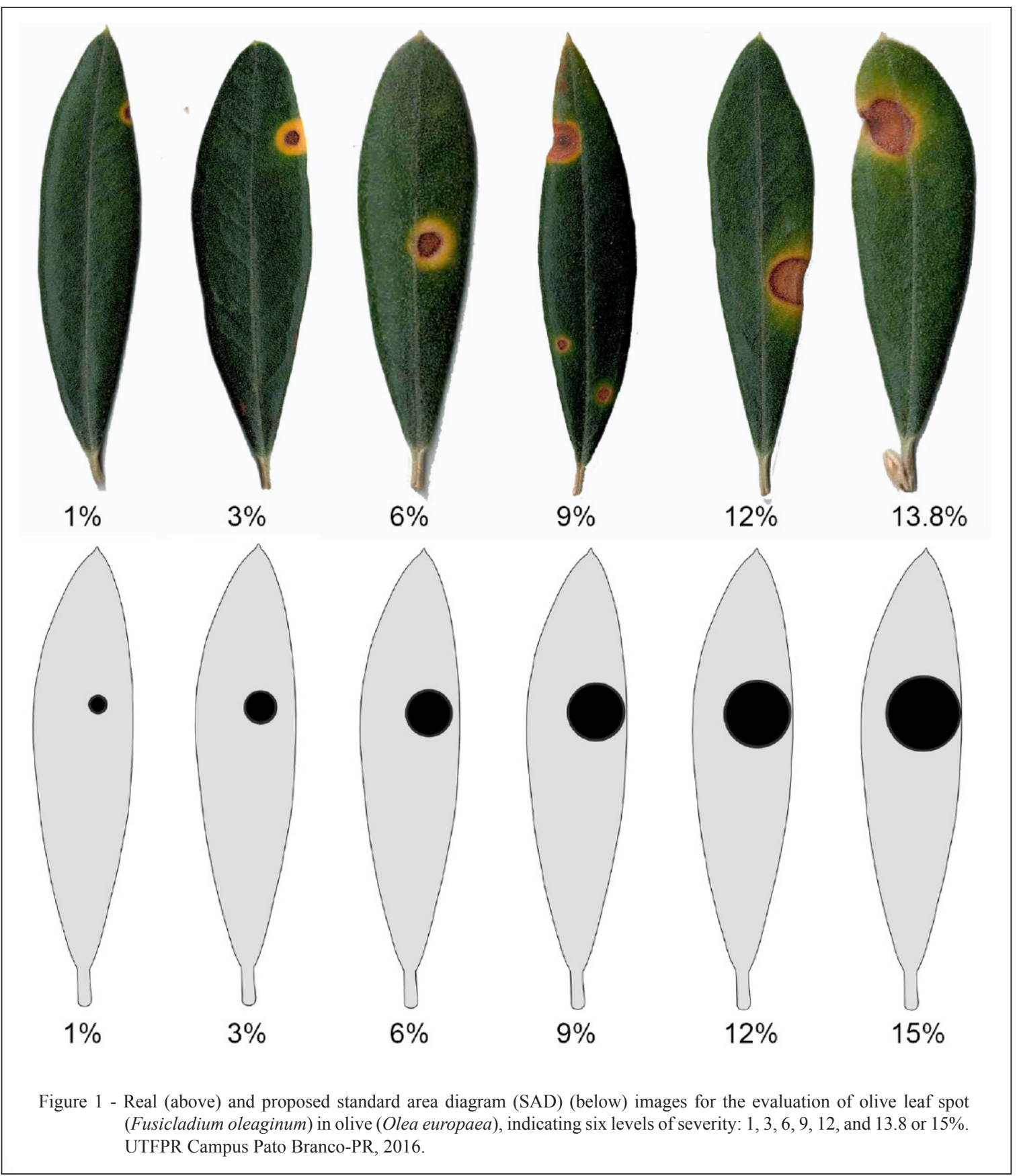

which it can be stated that there was a difference between observations (Table 1).

The SAD set presented here, with the disease severities illustrated representing stages of OLS, was shown to be easy to use, applicable under a wide variety of conditions and provided reliable results, such as those presented by Berger (1980). Representative symptoms of the disease were identified, and the maximum and minimum disease severity in the field was ascertained. Thus, the adoption of the SAD proposed in this paper to evaluate olive leaf spot severity, can reduce the subjectivity of the estimates and provided better information for epidemiological studies on the Fusicladium oleagineum Olea europaea pathosystem under humid subtropical climate conditions. 
Table 1 - Proposed standard area diagram set (SAD) on the visual estimate performance of olive leaf spot (Fusicladium oleagineum) severity on 50 olive (Olea europaea) leaves by eight raters. UTFPR Campus Pato Branco-PR, 2016.

\begin{tabular}{|c|c|c|c|c|}
\hline \multirow{2}{*}{ Variables $^{\mathrm{z}}$} & \multicolumn{2}{|c|}{---------------------------Means' } & \multirow{2}{*}{$\mathrm{MD}^{\mathrm{x}}$} & \multirow{2}{*}{ CI $(95 \%)^{\mathrm{w}}$} \\
\hline & With scale & Without scale & & \\
\hline $\mathrm{r}$ & $0.87(0.05)$ & $0.72(0.03)$ & $0.15(0.04)$ & 0.07 to $0.23^{*}$ \\
\hline$C_{b}$ & $0.98(0.01)$ & $0.91(0.03)$ & $0.07(0.02)$ & 0.02 to $0.12^{*}$ \\
\hline$u$ & $0.002(0.07)$ & $0.17(0.14)$ & $-0.168(0.07)$ & -0.31 to $-0.02^{*}$ \\
\hline$v$ & $1.01(0.02)$ & $1.15(0.09)$ & $-0.14(0.09)$ & -0.31 to $0.03^{\mathrm{ns}}$ \\
\hline$\rho_{c}$ & $0.86(0.06)$ & $0.66(0.05)$ & $0.20(0.04)$ & 0.12 to $0.28^{*}$ \\
\hline SDD & $1.91(0.48)$ & $3.91(0.41)$ & $-2.00(0.28)$ & 0.12 to $0.28^{*}$ \\
\hline
\end{tabular}

${ }^{\mathrm{z}} r$ : Precision, the correlation coefficient between estimated and real severity; $C b$ : a correction factor that measures how far away the adjusted line is in relation to concordant line (Accuracy); $u$ : difference between the line of regression and concordant line; $v$ : difference in the inclination between regression and concordant lines; $\rho_{c}$ : Lin`s concordant correlation coefficient. SDD: smallest detectable difference. ${ }^{\mathrm{y}}$ Standard error of mean in parenthesis $(n=8)$. ${ }^{\mathrm{x}}$ Mean Difference (MD) between each evaluation with mean standard error in parenthesis. ${ }^{\mathrm{w}}$ Confidence interval (CI) at $95 \%$ probability. Interval including zero, the difference is not significant $(\mathrm{P}>0.05)$; ${ }^{\text {ns. }}$. not significant, ${ }^{*}$ : significant.

\section{ACKNOWLEDGMENTS}

Plant materials evaluated in this research were obtained through the cooperative 'Xisto Project', conducted by Embrapa - Clima Temperado, Petrobras and Universidade Tecnológica Federal do Paraná (UTFPR). This research was partly funded by Coordenação de Aperfeiçoamento de Pessoal de Nível Superior (CAPES) and Fundação de Amparo a Pesquisa do Estado de Goiás(FAPEG). The authors acknowledge Bárbara Bonissoni Cella for her collaboration with data set collection.

\section{REFERENCES}

ALMEIDA, C.A.N.D. et al. Olive oil and its properties in hot preparations: literature review. International Journal of Nutrology, v.8, n.2, p.13-20, 2015. Available from: <http:// www.abran.org.br/RevistaE/index.php/IJNutrology/article/ viewFile/185/169>. Accessed: Oct. 07, 2016.

ALVARES, C.A. et al. Köppen's climate classification map for Brazil. Meteorologische Zeitschrift, v.22, n.6, p.711-728, 2013. Available from: <https://dx.doi.org/10.1127/0941-2948/2013/0507>. Accessed: Oct. 05, 2016. doi: 10.1127/0941-2948/2013/0507.

BERGER R.D. Measuring disease intensity. In: TENG, P.S.; KRUPA, S.V. Assessment of losses which constrain production and crop improvement in agriculture and forestry. St. Paul, MN: University of Minnesota, 1980. p.28-31.

CAVALHEIRO, C.V. et al. Chemical composition of olive leaves (Olea europaea L.) from the region of Caçapava do Sul, RS, Brazil. Ciência Rural, v.44, n.10, p.1874-1879, 2014. Available from: $<$ http://www.scielo.br/pdf/cr/v44n10/0103-8478-cr-44-10-01874. pdf $>$. Accessed: Oct. 05, 2016. doi: 10.1590/0103-8478cr20131139.

FAOSTAT, FAO. Food and Agriculture Organization of the United Nations Statistic Division. Available from: <faostat.fao.org>. Accessed: Oct. 07, 2016.

MacDONALD A.J. et al. Survey of olive leaf spot in New Zealand. New Zealand Plant Protection, v.53, p.126-132, 2000. Available from: $<$ https://nzpps.org/journal/53/nzpp_531260.pdf $>$. Accessed: Oct. 05,2016

MARTÍN-PELÁEZ, S. et al. Health effects of olive oil polyphenols: recent advances and possibilities for the use of health claims. Molecular Nutrition \& Food Research, v.57, n.5, p.760-771, 2013. Available from: <https://dx.doi.org/10.1002/mnfr.201200421>. Accessed: Oct. 06, 2016. doi: 10.1002/mnfr.201200421.

NICOLI, A. et al. Diagrammatic scale validation to quantify the severity of anthracnose stalk in corn. Ciência Rural, v.45, n.10, p.1720-1726, 2015. Available from: <http://www.scielo.br/pdf/ cr/v45n10/1678-4596-cr-0103_8478cr20141510.pdf>. Accessed: Oct. 07,2016 . doi: 10.1590/0103-8478cr20141510.

OBANOR, F.O. et al. Effects of temperature, inoculum concentration, leaf age, and continuous and interrupted wetness on infection of olive plants by Spilocaea oleagina. Plant Pathology, v.60, p.190-199, 2011. Available from: <http://dx.doi.org/10.1111/j.1365-3059.2010.02370. $\mathrm{x}>$. Accessed: Oct. 06, 2016. doi: 10.1111/j.1365-3059.2010.02370.x.

OLIVEIRA, M.C. et al. Phenological and physical characteristics and fatty acids of olive trees from the south of Minas Gerais, Brazil. Pesquisa Agropecuária Brasileira, v.47, n.1, p.30-35, 2012. Available from: $<$ http://www.scielo.br/pdf/pab/v47n1/47n01a05.pdf $>$. Accessed: Oct. 06, 2016. doi: 10.1590/S0100-204X2012000100005.

PENSO, G.A. et al. Spread of 'Koroneiki' Olive by the cutting method at different times, AIB concentrations and the presence of leaves. Ceres, v.63, n.3, p.355-360, 2016. Available from: $<$ http://www. scielo.br/pdf/rceres/v63n3/2177-3491-rceres-63-03-00355.pdf >. Accessed: Oct. 05, 2016. doi: 10.1590/0034-737X201663030012.

RICALDE, M.P. et al. Insects related to Olive culture in Rio Grande do Sul State, Brazil. Ciência Rural, v.12, p.1225-1230, 2015. Available from: <http://www.scielo.br/pdf/cr/v45n12/16784596-cr-0103_8478cr20141477.pdf>. Accessed: Oct. 05, 2016. doi: $10.1590 / 0103-8478 \mathrm{cr} 20141477$.

ROUBAL, C. et al. Field models for the prediction of leaf infection and latentperiod of Fusicladiumoleagineum on olive based on rain, temperature 
and relative humidity. Plant Pathology, v.62, n.3, p.657-666, 2013. Available from: $<$ https://dx.doi.org/10.1111/j.1365-3059.2012.02666.x>. Accessed: Oct. 06, 2016. doi: 10.1111/j.1365-3059.2012.02666.x.

SCHUBERT, K. et al. A monograph of Fusicladium s. lat. (hyphomycetes). Schlechtendalia, v.9, p.1-132, 2003. Available from: $<$ http://public.bibliothek.uni-halle.de/index.php/schlechtendalia/ article/view/316>. Accessed: Oct. 07, 2016.

SACHET, M.R. et al. DiseasePlan: a spreadsheet application for training people to assess disease severity and to assist with standard area diagram development. Ciência Rural, 2016 (submitted manuscript Oct. 8, 2016).

TERAMOTO, J.R.S. et al. Mercado dos produtos da oliveira e os desafios brasileiros. Informações Econômicas, v.43, n.2, 2013 Available from: <http://www.iea.sp.gov.br/ftpiea/publicacoes/ ie/2013/tec2-0413.pdf>. Accessed: Oct. 7, 2016.
VOGEL, P. et al. Polyphenols benefits of olive leaf(Olea europaea L.) to human health. Nutrición hospitalaria, v.31, n.3, p.1427-1433, 2015. Available from: <http://www.nutricionhospitalaria.com/pdf/8400. pdf $>$. Accessed: Oct. 06, 2016. doi: 10.3305/nh.2015.31.3.8400.

WREGE, M.S. et al. Potencial distribution of olive in Brazil and worldwide. Revista Brasileira de Fruticultura, v.37, n.3, p.656-666, 2015a. Available from: <http://www.scielo.br/pdf/rbf/ v37n3/0100-2945-RBF-37-3-656.pdf>. Accessed: Oct. 05, 2016 doi: 10.1590/0100-2945-174/14.

WREGE, M.S. et al. Regions with climatic similarity to commercial cultivation of olive tree in Brazil. Revista Brasileira de Climatologia, v.16, p.142-158, 2015b. Available from: $<$ https://www.embrapa.br/florestas/busca-de-publicacoes/-/ publicacao/1022996/regioes-de-clima-homogeneo-no-brasil-paraproducao-comercial-de-oliveiras $>$. Accessed: Oct. 07, 2016. 